\title{
Reaction of human smooth muscle autoantibody with gastric parietal cells: a pitfall in the diagnosis of parietal cell autoantibody
}

\author{
R. CEREDIG AND B. H. TOH
}

From the Department of Pathology and Immunology, Monash University Medical School, Commercial Road, Prahran, Melbourne 3181, Australia

SUMMARY Thirteen smooth muscle antibody (SMA) sera obtained from patients with active chronic hepatitis were examined for immunofluorescence reactivity with gastric mucosal cells. Eight out of 13 sera stained the cytoplasm of gastric parietal cells in a pattern indistinguishable from that obtained with parietal cell autoantibody (PCA). The staining reaction was localised to parietal cells by the demonstration that the same cells stained with both SMA and PCA in double immunofluorescent tests. The SMA staining intensity for parietal cells was weaker than that for smooth muscle. Specificity of the staining reaction for actin was established by the observation that parietal cell staining by SMA was inhibited by serum absorption with skeletal muscle F-actin but not by a microsomal fraction derived from gastric mucosa.

Smooth muscle antibody (SMA) found in the blood of some patients with active chronic hepatitis (Johnson et al., 1965; Doniach et al., 1966; Whittingham et al., 1966) has been shown to react with normal (Gabbiani et al., 1973; Toh et al., 1976e), neoplastic (Toh and Muller, 1975; Gabbiani et al., 1975; Toh et al., 1976a, b, c), and fetal (Toh et al., 1976d) non-muscle tissues. In normal and neoplastic tissues, the SMA-binding sites correspond to those in which microfilaments have been demonstrated ultrastructurally (Gabbiani et al., 1973, 1975; Toh et al., 1976c). The anti-actin specificity of these SMA sera has been established by the demonstration that all their staining reactions are inhibited by serum absorption with smooth or skeletal muscle actin (Botazzo et al., 1976; Lidman et al., 1976; Toh et al., 1976e) but not by skeletal muscle myosin, tropomyosin or troponin (Toh et al., 1976e). Further, eluates obtained by acid dissociation of SMA-actin precipitates have given the same staining patterns in tissues as the original sera (Lidman et al., 1976).

Although it has been noted previously that SMA stains the apices (Holborow et al., 1975) and cytoplasm (Botazzo et al., 1976) of gastric mucosal cells, there have been no definitive studies on this topic. The present study demonstrates that SMA

Received for publication 11 January 1977 from patients with active chronic hepatitis binds to the cytoplasm of parietal cells in a pattern indistinguishable from that obtained with parietal cell autoantibody (PCA).

\section{Material and methods}

PATIENTS' SERA

These comprised 13 sera from patients with active chronic hepatitis and three PCA sera from patients with pernicious anaemia. The SMA and PCA sera had staining titres of $\geqslant 32$ for smooth muscle and parietal cells respectively.

The SMA sera were characterised by reactivity $\frac{7}{0}$ with skeletal muscle striations, hepatocytes in a 'polygonal' pattern, renal glomeruli in a diffuse $\mathcal{N}$ pattern, and thymus medulla.

All sera were used fresh or stored at $-30^{\circ} \mathrm{C}$ for $N$ up to four years when they were rapidly thawed in a $37^{\circ} \mathrm{C}$ waterbath and tested at a dilution of $1: 8$.

\section{IMMUNOFLUORESCENCE TESTS}

The sera were examined by standard sandwich immunofluorescence tests with $6 \mu \mathrm{m}$ composite sections of mouse stomach, rabbit liver, and rat kidney (Nairn, 1976) and with sections of stomach $\frac{\Im}{\mathbb{D}}$ obtained from human, guinea-pig, rabbit, and rat $\varrho$ sources; specimens of human stomach were freshly 
obtained from patients undergoing partial gastrectomy. All tissues were snap-frozen in an isopentaneliquid nitrogen slurry and stored at $-70^{\circ} \mathrm{C}$.

The conjugate for immunofluorescent tracing of bound immunoglobulin was a fluorescein-isothiocyanate (FITC)-labelled goat anti-human-gamma globulin with a fluorescein to protein molar ratio of 4:0 and a protein content of $0.88 \mathrm{~g} / \mathrm{dl}$. For double immunofluorescent tracing, a rhodamine-labelled goat anti-human-gamma globulin with a rhodamine to protein ratio of $4: 1$ and a protein content of $4 \mathrm{~g} / \mathrm{dl}$ was used. After immunofluorescent staining, the microscopical sections were examined by darkground ultraviolet fluorescent microscopy using a condenser fitted with a toric lens and a colourless barrier filter.

\section{IMMUNOABSORPTION EXPERIMENTS}

SMA and PCA sera were absorbed with skeletal muscle F-actin prepared as described by Clarke $e t$ al. (1976), or absorbed with a microsomal fraction derived from the gastric mucosa prepared by the method of Ward and Nairn (1967). Immunoabsorption with skeletal muscle actin was carried out by adding 0.05 $\mathrm{ml}$ of serum to $0 \cdot 1,0 \cdot 2,0 \cdot 4,0 \cdot 7,1 \cdot 2,1 \cdot 6$, and $2 \cdot 0 \mathrm{mg}$ of actin, while immunoabsorption with the gastric microsomal fraction was carried out by adding one drop of the microsomal fraction to one drop of serum (Ward and Nairn, 1967).

The mixtures of sera and F-actin, or sera and the gastric microsomal fraction, were incubated overnight at $4^{\circ} \mathrm{C}$, and the supernatants were recovered by centrifugation at $10000 \mathrm{~g}$ for 30 minutes (Nairn, 1976).

\section{Results}

IMMUNOFLUORESCENT STAINING

In longitudinal sections of mouse stomach, 8/13 SMA sera stained not only smooth muscle fibres but also the cytoplasm of gastric mucosal cells (Fig. 1). The staining pattern of the latter was indistinguishable from that obtained with PCA (Fig. 2). In transverse sections of gastric mucosa, cytoplasmic staining was restricted to a few glandular cells and was largely basal and lateral in location (Fig. 3). In addition, the gastric glands also showed staining of the cell apices and the cell periphery; the latter were outlined in a linear pattern(Fig. 3). Double immunofluorescent staining with FITC- and rhodamine-conjugates revealed that the cytoplasm of the same cells stained with both SMA and PCA. A

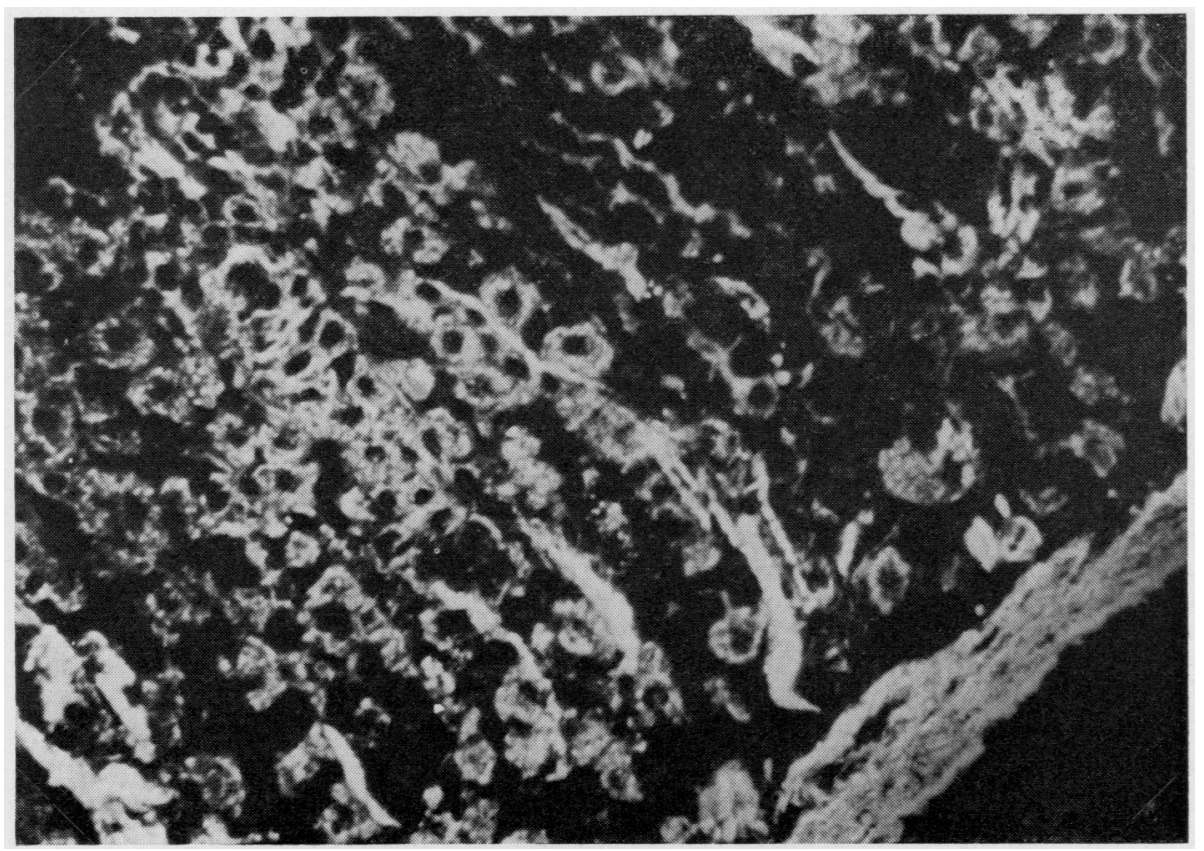

Fig. 1 Longitudinal section of mouse stomach reacted with SMA showing immunofluorescent staining of smooth muscle fibres and the cytoplasm of mucosal cells $\times 320$. 


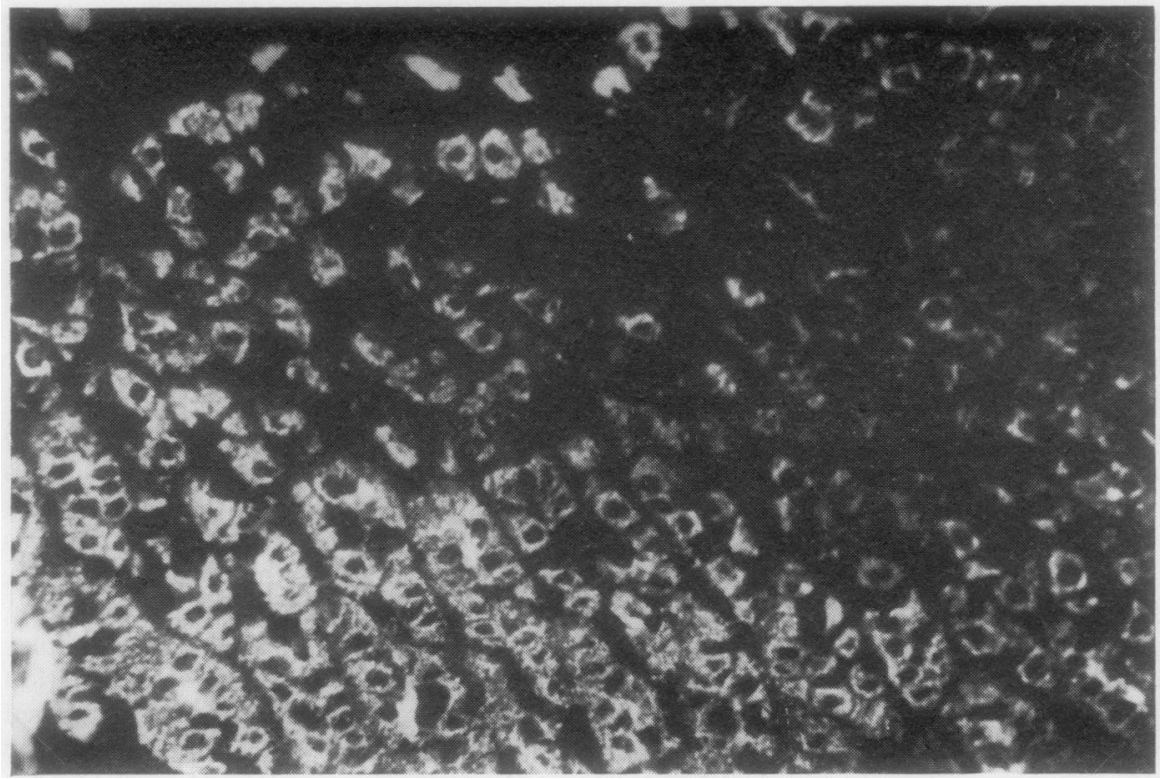

Fig. 2 Longitudinal section of mouse stomach reacted with PCA showing immunofluorescent staining of gastric parietal cells $\times 320$.

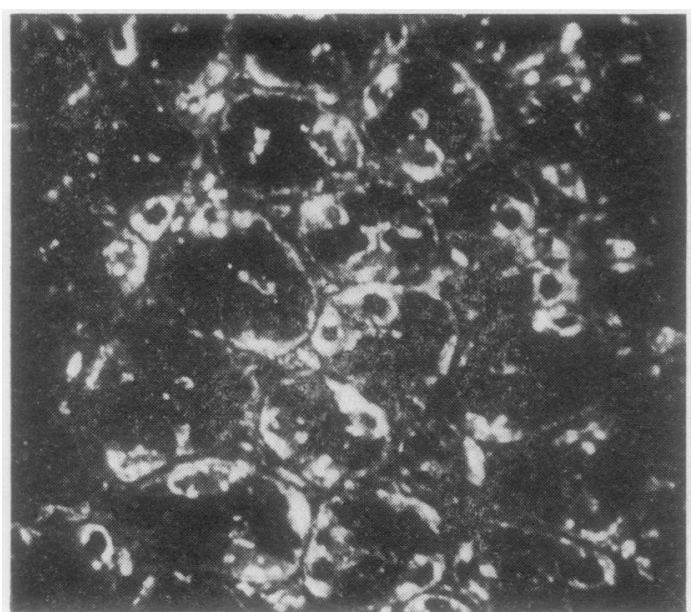

Fig. 3 Transverse section of mucosa of mouse stomach reacted with SMA showing restriction of cytoplasmic staining to a few glandular cells. In gastric glands, the cell apices and cell periphery are also stained. Indirect immunofluorescence $\times 270$.

similar pattern of staining was seen also in sections of human, guinea-pig, rabbit, and rat stomach.

The intensity of SMA staining of mucosal cells was weaker than that of smooth muscle. This was confirmed by titrations of SMA sera against sections of mouse stomach which showed that titres for mucosal cells were two to three tube dilutions less than those for smooth muscle (Table).

Table SMA staining titres for smooth muscle and gastric parietal cells

\begin{tabular}{rllllll}
\hline \multirow{2}{*}{$\begin{array}{l}\text { Parietal } \\
\text { cell titre }\end{array}$} & \multicolumn{9}{l}{ Smooth muscle titre } & & & \\
\cline { 2 - 7 } & $\leqslant 8$ & 16 & 32 & 64 & 128 & 256 \\
\hline$<8$ & 0 & 0 & 5 & 0 & 0 & 0 \\
8 & 0 & 0 & 0 & 1 & 0 & 0 \\
16 & 0 & 0 & 0 & 1 & 3 & 0 \\
32 & 0 & 0 & 0 & 0 & 0 & 1 \\
64 & 0 & 0 & 0 & 0 & 1 & 1 \\
\hline
\end{tabular}

IMMUNOABSORPTION EXPERIMENTS

Parietal cell staining by SMA was completely $\tilde{N}$ inhibited by serum absorption with skeletal muscle $\tilde{\omega}^{N}$ F-actin but not by the microsomal fraction derived $O$ from gastric mucosa. In contrast, parietal cell 0 staining by PCA was inhibited by serum absorption with the gastric microsomal fraction but not by $\stackrel{\oplus}{+}$

F-actin.

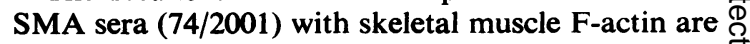
shown in Figure 4. This figure shows that absorption $\stackrel{\mathbb{Q}}{\circledR}$ of $0.05 \mathrm{ml}$ of serum with $0.1 \mathrm{mg} \mathrm{F}$-actin completely inhibits parietal cell staining whereas, for the same 


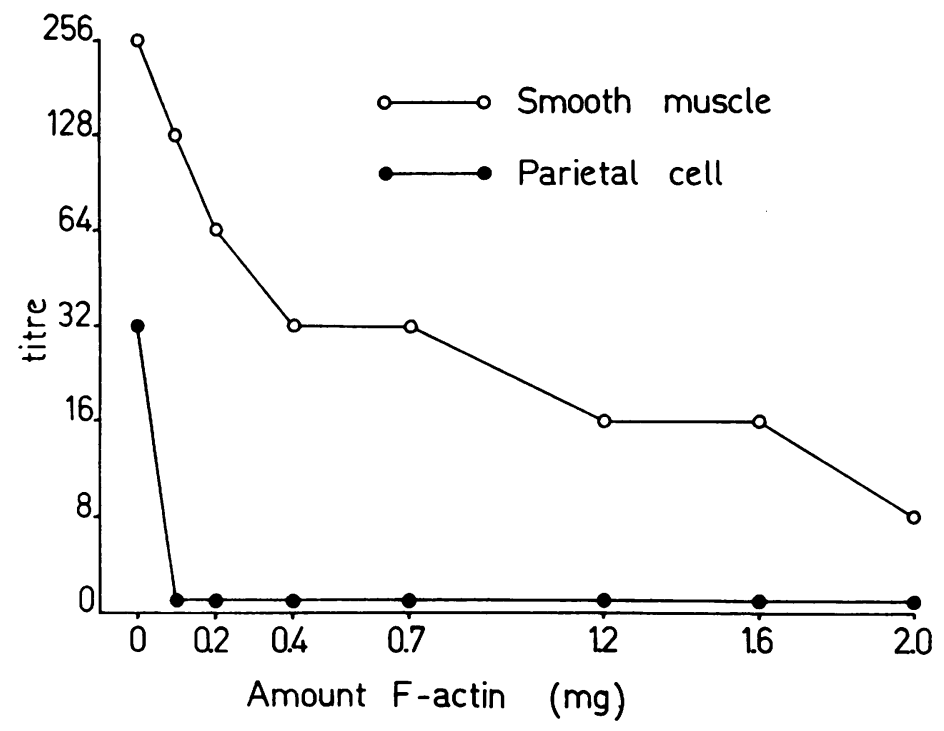

Fig. 4 Results of immunoabsorption of SMA serum 74/2001 with skeletal muscle F-actin: - parietal cells; $\bigcirc-\bigcirc$ smooth muscle cells.

volume of serum, $2.0 \mathrm{mg}$ F-actin is required to neutralise smooth muscle staining.

\section{Discussion}

The results show that 8/13 SMA sera from patients with active chronic hepatitis reacted with the cytoplasm of gastric parietal cells in a pattern indistinguishable from that obtained with PCA. Localisation of staining to parietal cells was established by the demonstration that the same cells stained with both SMA and PCA in double immunofluorescence tests using FITC- and rhodamineconjugates. An identical pattern of parietal cell staining is also obtained with mitochondrial autoantibody (Walker, 1974). A confident diagnosis of PCA cannot therefore be made when SMA or mitochondrial autoantibody is present in the same serum.

Immunoabsorption studies showed that the SMA staining of parietal cells is due to binding to actincontaining sites in the cytoplasm because the staining reaction was completely abolished by serum absorption with skeletal muscle F-actin but not by a microsomal fraction derived from gastric mucosa. In contrast, parietal cell staining by PCA was abolished by serum absorption with the gastric microsomal fraction but not by skeletal muscle actin.

The staining intensity of SMA for parietal cells is weaker than that for smooth muscle. This was confirmed by serum titrations against sections of mouse stomach which showed that titres for parietal cells were two to three tube dilutions less than those for smooth muscle. Immunoabsorption studies also showed that the amount of skeletal muscle actin required to inhibit SMA staining of parietal cells was less than that required to neutralise SMA reactivity with smooth muscle.

The basal and lateral portions of parietal cells, where most of the SMA staining occurs, contain an elaborate system of surface invaginations (secretory canaliculi; Porter and Bonneville, 1968). These canaliculi penetrate the cytoplasm lateral to the nucleus and communicate by a common outlet with the lumen of the gastric gland. As these canaliculi are the sites of acid secretion by parietal cells, we suggest that actin may play a role in this process. Ultrastructural studies with immunoperoxidase labelling are currently in progress to locate more precisely the intracellular sites which bind SMA.

We thank Professor R. C. Nairn for advice, Miss Vivien Randell for technical assistance, Dr F. M. Clarke for the gift of F-actin, and Dr H. A. Ward for the gastric microsomal fraction. Support by the Anti-Cancer Council and the National Health and Medical Research Council is acknowledged.

\section{References}

Botazzo, G. F., Florin-Christensen, A., Fairfax, A., Swana, G., Doniach, D., and Groeschel-Stewart, U. (1976). Classification of smooth muscle autoantibodies 
detected by immunofluorescence. Journal of Clinical Pathology, 29, 403-410.

Clarke, F. M., Lovell, S. J., Masters, C. J., and Winzor, D. J. (1976). Beef muscle troponin: evidence for multiple forms of troponin-T. Biochimica et Biophysica Acta, 427, 617-626.

Doniach, D., Roitt, I. M., Walker, J. G., and Sherlock, S. (1966). Tissue antibodies in primary biliary cirrhosis, active chronic (lupoid) hepatitis, cryptogenic cirrhosis and other liver diseases and their clinical implications. Clinical and Experimentql Immunology, 1, 237-262.

Gabbiani, G., Ryan, G. B., Lamelin, J. P., Vassalli, P., Majno, G., Bouvier, C. A., Cruchaud, A., and Lüscher, E. F. (1973). Human smooth muscle autoantibody. American Journal of Pathology, 72, 473-484.

Gabbiani, G., Trenchev, P., and Holborow, E. J. (1975). Increase of contractile proteins in human cancer cells. Lancet, 2, 796-797.

Holborow, E. J., Trenchev, P. S., Dorling, J., and Webb, J. (1975). Demonstration of smooth muscle contractile protein antigens in liver and epithelial cells. Annals of the New York Academy of Sciences, 254, 489-504.

Johnson, G. D., Holborow, E. J., and Glynn, L. E. (1965). Antibody to smooth muscle in patients with liver disease. Lancet, 2 , 878-879.

Lidman, K., Biberfeld, G., Fagraeus, A., Norberg, R., Torstensson, R., Utter, G., Carlsson, L., Luca, J., and Lindberg, U. (1976). Anti-actin specificity of human smooth muscle antibodies in chronic active hepatitis. Clinical and Experimental Immunology, 24, 266-272.

Nairn, R. C. (1976). Fluorescent Protein Tracing, 4th edition. Churchill Livingstone, Edinburgh.

Porter, K. R. and Bonneville, M. A. (1968). Fine Structure of Cells and Tissues, 3rd edition. Lea and Febiger, Philadelphia.
Toh, B. H. and Muller, H. K. (1975). Smooth muscleassociated antigen in experimental cutaneous squamous cell carcinoma, keratoacanthoma and papilloma. Cancer Research, 35, 3741-3745.

Toh, B. H., Muller, H. K., and Elrick, W. L. (1976a). Smooth muscle associated antigen in astrocytes and astrocytomata. British Journal of Cancer, 33, 195-202.

Toh, B. H., Muller, H. K., and Cauchi, M. N. (1976b). Smooth muscle-associated contractile protein in human and experimental acute leukaemias. Australian and New Zealand Journal of Medicine, 6, 459-462.

Toh, B. H., Hard, G. C., Cauchi, M. N., and Muller, H. K. (1976c). Smooth-muscle-associated contractile protein in renal mesenchymal tumour cells and in transformed cells from DMN-injected rats. British Journal of Cancer, 34, 533-545.

Toh, B. H., Muller, H. K., and Cauchi, M. N. (1976d). Reaction of human smooth muscle antibody with foetal glial cells and their precursors. Australian Journal of Experimental Biology and Medical Science, 54, 423-430.

Toh, B. H., Gallichio, H. A., Jeffrey, P. L., Livett, B. G., Muller, H. K., Cauchi, M. N., and Clarke, F. M. (1976e). Anti-actin stains synapses. Nature, 264, 648-650.

Walker, G. (1974). The immunology of liver disorders. Proceedings of the Royal Society of Medicine, 67, 566-573.

Ward, H. A. and Nairn, R. C. (1967). Extraction of gastric parietal cell autoantigen. Clinical and Experimental Immunology, 2, 565-571.

Whittingham, S., Mackay, I. R., and Irwin, J. (1966) Auto-immune hepatitis: immunofluorescence reactions with cytoplasm of smooth muscle and renal glomerular cells. Lancet, 1, 1333-1335. 